\title{
A LEGALIDADE NA RELAÇÃO ENTRE MINISTÉRIOS E AGF̂NCIAS REGULADORAS
}

\author{
Thiago Marrara \\ Mestrando em Direito do Estado da Faculdade de \\ Direito da Universidade de São Paulo.
}

Resumo:

O presente artigo parte da idéia de funções estatais para analisar a relação de legalidade que deve prevalecer nas relações entre Ministérios e Agências Reguladoras no âmbito do Ordenamento Jurídico brasileiro.

Abstract:

This essay presents an analysis of the legal administrative relations between Ministries and Public Regulatory Agencies in Brazil taking as its guide the role and types of State Functions in Public Law.

Unitermos: Ministérios; Agências reguladoras; princípio da legalidade.

Keywords: Ministries; Public Regulatory; agencies; legality.

"As faculdades, nas funções ou atribuições, decorrem do poder dividido ou da participação de competência, provendo a Administração dos motivos para ajustar o querer-vontade ao realizar-finalidade" (FRANCO SOBRINHO, Manoel de Oliveira. Obrigações administrativas. Rio de Janeiro, Forense, 1983, p. 40).

I. Introdução.

O fulcro do presente trabalho é o princípio da legalidade e o excrcício de função administrativa, normativa ou não-normativa, pela Administração Pública.

A fim de nortear seu desenvolvimento. optou-se por permeá-lo com um problema real, ilustrativo, e que refere à discussão sobre o padrão legalidade que envolve a relação entre Ministérios e agências reguladoras no contexto jurídico pátrio.

Dentro dessa tcmática, primeiramente, aventurou-se a desenhar abstratamente um método de busca do bloco normativo com o qual as decisões e atividades administrativas, principalmente de feição normativa, devem firmar uma 
relação de legalidade. Para tanto, parte-se do reconhecimento das complexidades do ordenamento juridico, passando-se por noções gerais sobre o princípio da legalidade e chegando-se à abordagem das funções estatais como instrumentos aptos a organizar as normas jurídicas adequadas a cada atividade dos agentes públicos.

Feito isso, analisou-se brevemente o referido caso concreto.

2. A complexidade dos ordenamentos: pluralismo, pluricentrismo e plurimodalidade normativa.

A reforma do Estado e a disseminação de órgãos e entes da Administração Pública Indireta com relativo grau de autonomia levantam, entre inúmeras, a discussão sobre o princípio da legalidade e o exercício do poderes normativo e não-normativo dentro do Poder Executivo.

Toda essa celeuma reflete e revela. no plano fundamental. a complexidade dos ordenamentos jurídicos, o que justifica as seguintes observações prévias, especialmente acerca da função normativa.

O surgimento de novos pólos de produção normativa deve ser compreendido em relação aos pólos já existentes. Ao operador do Direito cabe o trabalho de situar na unidade do ordenamento aquelas novas fontes como um pressuposto básico à compreensão da validade e aplicabilidade das normas por elas geradas.

No entanto, posicionar uma fonte normativa na maioria dos ordenamentos jurídicos não é uma tarefa fácil. Isto porque os sistemas normativos não seguem exatamente uma estrutura piramidal, pela qual as normas retirariam seu fundamento de validade de outras de maior grau hierárquico e de maior generalidade. '

De fato, não existem apenas relações normativas lineares, baseadas em causalidades. em relações de supra e infra-ordenação. A pluralidade de normas de um

1. Conferir a respeito dessa visão KELSEN, Hans. Teoria Pura do Direito. São Paulo: Martins Fontes, 1988. "A norma que regula a produção é a norma superior; a norma produzida segundo as determinações daquela é a norma inferior. A ordem juridica não é um sistema de normas juridicas ordenadas no mesmo plano. simadas umas ao lado das autras, mas é uma construção escalonada de diferentes camadas ou niveis de normas juridicas. A sua unidade é produto da conexão de dependència que resulta do faro de a validade de uma norma que foi produzida de acordo com outra norma (...)". p. 246-247. 
ordenamento não se reduz simplesmente a um esquema escalonado a partir de uma única norma fundamental e que configura uma unidade em última instância.

Numa visão menos formalista que a de Kelsen, poder-se-ia afirmar que o ordenamento jurídico remonta não uma única série normativa. mas diversas. Partindo de normas-origem geradas por preceitos jurídico-constitucionais decorrem escalões normativos distintos que convivem num padrão de coesão, compatibilidade. não de perfeita unidade.?

O reconhecimento da existência de séries normativas que brotam de normas-origem ou pólos normativos tem relação direta com qualquer análise que se pretenda empreender sobre as fontes normativas e o relacionamento que se dá entre elas sob a égide da ligalidade inafastável. A configuração de um ordenamento coeso deixa entrever uma complexidade que precisa ser reconhecida para que se possa traçar um padrão de legalidade nas relações entre órgãos e agentes públicos.

Essa complexidade pode ser reduzida a três pluralidades: uma pluralidade de normas; uma pluralidade de centros produtores de normas, designada pela expressão pluricentrismo; c uma pluralidade de veículos introdutores de normas, ou diplomas, a qual se pode chamar de plurimodalidade de atos normativos.

As duas expressões em itálico. cunhadas por Canotilho, ${ }^{3}$ nada mais revelam que a complexidade de se analisar um ordenamento jurídico, hierarquizando e alocando suas diversas fontes. Soma-se a elas, ainda. a natural pluralidade de

2. Sobre normas-origem e coesão do sistema juridico, vide FERRAZ JÚNIOR, Tércio Sampaio. Introdução au estudo do direiıo: técnica, decisão, dominação. São Paulo: Atlas, 1994. "Do ponto de vista pragmático, é preciso considerar validade e imperatividade como conceilos diferentes, não redutive is um ao outro, e o conceito de ordenamento como um sistema que admite não tana, nas vánias hicrarquias. u que elimina a hipótese de uma (única) norma fundamental e a correspondente concepção de unidade. p. 188. Ademais, a posição pragmática é de que o sistema do ordenamento. não se reduzindo a uma (única) unidade hierárquica, não tem a estrutura de uma pirâmide. mas uma estrutura circular de competências referidas mutuamente, dotada de coesâo". p. 187.

3. Canotilho, J. J. Gomes. Direito constitucional e teoria da constituição, 5. ed. Coimbra: Almedina. 2002. "Os exemplos anteriores revelam umas das caracteristicas fundamentais do actual sistema das fontes de direito: substituição dos velhos paradigmas da unidade de instâncias legiferantes e da unimodalidade dos actos legislativos pelo paradigma do pluralismo legislatino e planimodalidade de' actos legislativos" p. 691. V também FERRAZ JƯNIOR, ibidem, p. 235. 
normas que é comum a qualquer ordenamento, ${ }^{4}$ fechando-se ai três pluralidades geradoras de inegável complexidade que sc põe à frente de todo intérprete do Direito.

Em termos práticos, essa complexidade significa que, dentro da dinâmica de um sistema jurídico, as normas, em sua pluralidade, são produzidas por diversos pólos, em séries normativas lineares e geralmente paralelas, c positivadas por meio de muitas espécies de diplomas legais, incluindo-se aí as Constituições, as Leis em todas suas espécies, os Decretos, Regulamentos, as Instruções, Resoluções, Portarias etc. ${ }^{5}$

Imagine-se agora a relação de cada um desses diplomas entre si e a relação das normas que cada um deles traz ao ordenamento com todas as outras e entender-se-á claramente a dita complexidade dos sistemas jurídicos atuais, em que a hierarquia se torna difusa e novos conflitos normativos exsurgem - tal como os chamados conflitos diagonais de normas, na hipótese de entrecruzamento de normas jurídicas de séries diferentes.

As questões que se colocam aí são as mais variadas, mas, especificamente, o que se deseja verificar, nestas páginas, é a medida em que as atribuições normativas ministeriais se sobrepõem às tarefas das agências reguladoras, determinadas pelas leis que as instituem.

Qual o espaço que se reserva às orientações e instruções ministeriais dentro da linha de produção normativa das agências? Existe algum tipo de hierarquia de normas ou, ao contrário, são as Agências totalmente "independentes"? Qual a importância das normas constitucionais que dispõem sobre os Ministérios para situar o poder normativo que a eles se acomete? E enfím, quais as características do padrão de legalidade que envolve os Ministérios, como entes da Administração Direta, e as Agências Reguladoras, como entes da Indireta?

4. BobBIO, Norberto. Teoria do ordenamento juridico. Brasilia: Editora Universidade de Brasília, 1999. "Partamos de uma definição muito geral de ordenamento, que iremos passo a passo especificando: o ordenamento jurídico (como todo sistema normativo) é um conjunto de normas", p. 31 et seq.

5. Em valioso histórico sobre a lei perante a evolução do Estado, afirma Jorge MIRANDA que "ontes do iluminismo e da Revolução francesa, o peso da lei era (a despeito do esforço centralizador do Estado absoluto) relativamente pequeno; a lei e Direito objectivo não se confundiam, não só devido ao papel desempenhado pelo costume, mas tambèm devido à aceilação de certos principios éicojuridicas (...)" Teoria do esıado c da constituiçăo. Rio de Janeiro: Forense, 2002. p. 243. 
Antes de tentar responder algumas dessas questões, seria prudente revisitar o conceito de legalidade e suas relações com a administração pública, passando-se, depois, a alguns aspectos legais sobre os entes envolvidos.

3. Legalidade, administração e Estado de Direito.

Nos termos em que foi inscrita no art. 37, caput, da atual Constituição da República, a legalidade administrativa está estritamente ligada à idéia de Estado de Direito.

$\mathrm{Na}$ ciência jurídica do século XIX. iniciou-se a construção de um conceito de Estado de Direito pelo qual os órgãos estatais e os governantes, em suas atividades. deviam-se sujeitar à Lei. em sentido formal. como forma de proteger, ao final. a liberdade dos administrados e impedir decisões formalmente arbitrárias.

No início do século XX, pôs-se em discussão tal teoria, que equiparava - Estado de Direito au Estado de Leis, uma vez que a legislação também está vinculada ao ordenamento constitucional. aos direitos fundamentais e aos princípios jurídicos, notadamente o do respeito à dignidade humana. Larenz propôs um Estado de Direito de modo mais aberto. Seria, em feição pouco distinta, um modelo que se dedica à criação, ao desenvolvimento e à execução de condições para a realização da justiça, respeitando, para tanto, o ordenamento juridico por ele mesmo construido e seus principios sustentadores, não-necessariamente positivos. ${ }^{\circ}$

Somando-se essas diversas contribuições teóricas e considerando a ampliação do conceito de Direito, que absorveu noções de moralidade, justiça e funções sociais, pode-se afirmar que o conceito de Estado de Direito, hoje, resume-se a uma obrigatória imposição de juridicidade de todos os atos e condutas praticados, seja por particulares, seja pelos entes públicos. ${ }^{7}$

Essa juridicidade impõe um respeito inexorável ao ordenamento juridico como um todo, dentro do qual as normas aparecem como regras e princípios. Além disso, implica a vinculação dos atos juridicos em sentido amplo à consecução

6. V. em geral, LAREvZ, Karl. Derecho Justo. Madrid: Civitas. 1985.

7. Relação de juridicidade nada mais é do que legalidade perante o Direito com um todo. $\dot{E}$ preferivel usar relação de juridicidade em detrimento de relação de constitucionalidade e relação de legalidade, expressões que, não raro, assumem sentido estrito, quais sejam. vinculação estrita às nonmas constitucionais e às normas dos diplomas legislativos (entre outros sentidos variantes). 
da justiça, da redução das desigualdades sociais e outros macrovalores, tal como os indicados pelo art. $3^{\circ}$ da Constituição da República. ${ }^{8}$

Em outras palavras, praticamente não há ato humano e social, ressalvados unicamente aqueles restritos à intimidade como direito da personalidade. que não sofra ingerência do ordenamento, ainda que apenas pelas finalidades sociais yue se os obriga a atingir.

A atividade do Poder Público. por isso. não poderia escapar dessas imposições legais, muito mais quando serve a dois tipos de interesses públicos: uns primários, relativos aos interesses públicos sociais, vantajosos a todos indistintamente; e outros secundários, essencialmente, mas não-necessariamente, restritos ao Estado como pessoa jurídica de Direito Público, como mais um sujeito de direito sob os imperativos de um certo sistema normativo.

Com o desenvolvimento do Estado do Direito. afora o intuito de preservar os interesses públicos envolvidos. a legalidade administrativa teve sua função ampliada, afigurando-se tanto como uma mera forma de controle dos agentes públicos pela própria Administração. quanto como um mecanismo de proteção do particular.

A legalidade, pois. transformou-se em garantia dos administrados na medida em que obriga a atuação administrativa, sob fórmulas e modos prescritos legalmente.

Assim, sob pena de ferir interesses públicos. primários e secundários, e particulares. a Administraçăo Pública, ao agir, segue a vontade imediata da Legislação. A Lei determina para a Administração Pública quais são os elementos e os requisitos dos atos administrativos e. para além disso, quando devem ser praticados, por meio de qual procedimento e por qual sujeito. ${ }^{2}$

Esse padrão de legalidade administrativa supera. então. a concepção originalmente prevalecente e característica do modelo do Estado de Polícia para se enquadrar à concepção prevalecente de Estado de Direito, guardião de interesses

8. Constituição da República, art. 3o. Constituem objetivos fundamentais da República Federativa do Brasil: I - construir uma sociedade livre, justa e solidaria; II - garantir o desenvolvimento nacional; III - erradicar a pobrcza c a marginalização e reduzir as desigualdades sociais e regionais; IV promover o bem de todos, sem preconceitos de origem. raça, sexo, cor, idade e quaisquer outras fonmas de discriminação.

9. Z.ıNOBINı. Guido. L'attivitù amministrativa e la legge. Milão: Giuffrè, 1955, p. 203 cl seq. 
públicos difusos ou próprios da figura estatal, e protetor das liberdades dos particulares que se encontram em certo território sob sua égide.

Em bons termos, não há atividade do Estado à margem do Direito. ${ }^{10} \mathrm{O}$ principio da legalidade impede que qualquer órgão ou agente da Administração pública pratique atos que possam contender com interesses alheios, privados ou públicos indisponíveis, senão em virtude de uma norma geral anterior. ${ }^{11}$

4. Identificando a legalidade por meio de funções estatais.

Se a Administração Pública está sujeita à estrita legalidade. mas tal princípio não-redunda numa simples repetição e execução de regras jurídicas e sim. muito mais, enseja um condão de juridicidade, resta a intrigante dúvida sobre como cada um dos órgãos administrativos, em sentido amplo, busca e forma o bloco normativo geral que sustenta suas atividades, ainda mais frente às três pluralidades que permeiam todo ordenamento jurídico.

Como o agente público, na formulação de uma vontade institucional e estatal. vai constituir o arcabouço jurídico que o leva a agir ou deixar de agir desta ou dayuela maneira? Qual o "bloco de legalidade" que norteia e autoriza suas ações?

Obviamente. não é crível que se possa definir aqui uma resposta geral. Contudo, pela ótica utilitarista, parece suficiente que se recorra a idéia de séries normativas, enquadrando-as em funções estatais. Desse modo, possivelmente se logre solucionar a questão, ainda que superficialmente.

Se o Estado depende de normas, seja como forma de proteção de interesses, seja pelo fato de se identificar com o Direito. ${ }^{12}$ todos os atos c funções estatais são, no fundo, atos e funções juridicas. ${ }^{13}$

Essas funções estatais, banhadas pelo Direito, podem ser tripartidas com base em critérios de finalidade, especialidade segundo a matéria, modos de

10. MIRANDA, Jorge. Teoria do éstado e da constituição. Rio de Janciro: Forense, p. 232.

11. Caetano, Marcello. Manual de direito administrativo. Rio de Janeiro: Forense, 1970, p. 30.

12. KELSEN identifica o Estado com a ordem jurídica, de modo que para atuar o Estado sempri depende de norma. Funcionalmente. no entanto, a legalidade, seja como requisito de existência du Estado, seja como forma de tutela de diversos interesses, chega aos mesmos termos, na medida que, nos dois casos, ela se amplia ou se reduz de acordo com o maior ou menor âmbito de atuação estatal.

13. MIRANDA, ibidem, loc. cit. 
manifestação e grau de institucionalização, consoante sugere Miranda. Nessa linha, existiria: I) uma função política, subdividida em função governativa (gubernatio) e legislativa (legislatio): 2) uma função administrativa e; 3) uma função jurisdicional. ${ }^{14}$

A função governativa e a função legislativa. como parcelas da função política, partilham dos mesmos valores e do mesmo enquadramento institucional, de modo que nenhuma das decisões em que se desdobram podem seguir rumos distintos, indiferentes ou contraditórios.

A função política se exerce mediante a definição dos grandes interesses públicos, infra-ordenados unicamente aos objetivos do Estado - no caso brasileiro, enumerados no art. $3^{\circ}$ da Constituição da República. Em vista da vagueza dessas amarras constitucionais, a função, em tela. caracteriza-se por uma discricionariedade máxima, cujas regras de exercicio são abertas e carentes de sanção. ${ }^{15} \mathrm{Na}$ função politica, pois, as escolhas e as tomadas de decisão geralmente não se sujeitam a prazos estabelecidos pelo Direito, nem há circunstâncias que as impõem, restando ilógica qualquer pretensão sancionatória, que não sejam aquelas de caráter social e político. $^{16}$

A função administrativa, de outro lado, conduz-se para a satisfação das necessidades coletivas, sejam elas essenciais (desfrutáveis por todos difusamente) ou instrumentais (que servem a todos, mas individualmente dentro de seus objetivos privados). ${ }^{17}$

Nesta tarefa, o Estado age por iniciativa própria, de oficio, e segundo um critério de parcialidade, ou seja, escolhendo de que forma deseja atender aos administrados. Operacionalmente, a fim de atingir finalidades escolhidas, estruturamse órgãos, que cooperam horizontal ou verticalmente, de forma mais ou menos

14. MIRANDA, ibidem, p. 236-237. No contexto, não caberá discorrer sobre a função jurisdicional.

15. Carentes de sanção dentro da discricionariedade ampla. Nada impede que atos praticados no exercício da função politica sejam apreciados pelo Judiciário, ainda mais quando o Direito absorve a moralidade e outros valores em normas constitucionais.

16. Para CaEtano, a função politica é definida como a "actividade dos órgãos do Eslado cujo objecto directo e imediato é a conservação da sociedade politica e a definição e pressecução do interessi geral mediante a livre escolha dos rumos on soluções consideradas preferiveis"p. 8. Para ese autor, tal função se exerce principalmente na fase de elaboração legislativa. mas influi na atuação dos orgãos que dependem e cooperam com o governo.

17. As espécies de necessidade social foram emprestadas de CAETANO. Marcello. Momual de direito administrativo. Rio de Janciro: Forense, 1970, p. 02 et seq. 
descentralizada e em quantidade dependente do grau de desconcentração das atividades.

Observe-se, em tempo, que a parcialidade característica da função administrativa não-significa desrespeito ao tratamento isonômico dos administrados nem inaptidão da Administração para a prática de atos normativos, abstratos e gerais, como se verificará mais para frente.

Em poucas letras, disso tudo se depreende que existem atos de direção e controle que refletem a plenitude do poder soberano como poder autônomo, e estes são os atos que integram a função política que se rege, em geral, pela máxima "permissum videtur in omne quod non prohibitur" De outra parte, existem os atos subordinados ou derivados, que supõem o emprego derivado do poder e que, por conseguinte. sujeitam-se à estrita legalidade ." quac non sunt permissac, prohibita intelliguntur" Eis aqui a função administrativa. ${ }^{18}$

5. O ato normativo nas funções do Estado.

Em todas as aduzidas funções estatais (política, administrativa e jurisdicional) subsistem espécies de poder normativo. Isto porque o ato normativo é gênero, no qual se incluem mais do que leis em sentido formal. Grosso modo, o ato normativo é todo ato de conteúdo geral e abstrato, dos quais são exemplos as leis, os regulamentos, os regimentos, as instruções, entre outros que não se restringem à esfera do Poder Legislativo. O poder normativo, do qual é produto um ato normativo, ainda que se concentre na função política, é atributo também da função jurisdicional e administrativa. ${ }^{19}$

Desta maneira, são atos normativos tanto uma lei em sentido material quanto um regulamento. Entretanto, pode haver leis em sentido formal que não são atos normativos (como as leis de efeitos concretos); da mesma forma que alguns atos administrativos e atos jurisdicionais não o são, tais como os contratos administrativos e as sentenças, ambos pela carência de abstração.

18. HERAS, Jorge Xifras. El gobierno y la funcion politica. In Gobierno y administracion en la constitucion. Espanha: Instituto de Estúdios Fiscales, 1988, p. 1.843-1.851.

19. V. perfilhando a mesma opinião, GRAL, Eros Roberto. O direito posto e o direito pressuposto. São Paulo: Malheiros, 2000. p. 182-183. 
Importa apenas que, dentro da função administrativa, reconheça-se um poder normativo, revelado por ccrtas categorias de atos, tal como o regulamento, as instruções e os estatutos. Esses atos, cada um por suas características e fundamento lugal superior, participam de uma série normativa que deflue da Constituição e se comunica com a função administrativa; e o princípio da legalidade, aí, como instrumento de tutela de interesses públicos e privados, dá forma a essas séries ao selecionar quais normas the podem ou-não pertencer.

Agora, volte-se, então, à questão de saber como o agente público pode definir o bloco normativo ao qual deverá reportar para conferir legalidade às atividades que deseja realizar ou a decisão que deve tomar. Propõe-se ai, então, que: 1) primeiramente, o agente desvende a função que agasal ha as atividades que pretende exercer e as decisões que pretende tomar; 2) em seguida. situe as séries normativas que lhe dizem respeito, primordialmente pela matéria juridica tratada: e 3) finalmente, hierarquize as normas e diplomas escolhidos.

Nesse caminho, evita-se o risco de se perder por entre as pluralidades normativas dos ordenamentos, hierarquizando elementos de séries normativas distintas. construindo falaciosas relações de legalidade, guiando-se por liberdades inadequadas à função, e sujeitando-se a regras e princípios inaplicáveis. Tudo isso, sob o risco de ferir dos mais amplos e difusos aos mais privados direitos.

Lm síntese, o manuseio das funções estatais para operacionalizar e posicionar as normas juridicas, mostra-se razoavelmente apto para afastar a complexidade dos ordenamentos. em tudo plurais. beneficiando a certeza e o bom enquadramento das relações de juridicidade.

6. Um caso concreto: Ministérios e Agências Reguladoras.

Essa proposta. brevemente esboçada, de busca do bloco de legalidade, necessário ao exercício das atividades de agentes e órgãos de Direito Público, traz como fundamento genético o desejo de se compreender justamente a vinculação jurídica de dois entes da Administração Pública: um da Administração Direta, outro da Indireta, cada um no exercício de suas funções públicas, notadamente administrativas.

Refere-se, açui, especificamente a relação de juridicidade que deve ser estabelecida entre Ministérios e Agências Reguladoras, sob a luz do Ordenamento 
pátrio. Relação que remonta questões supracitadas. Reitere-se, em resumo: qual o modelo de legalidade que se impõe entre atos normativos ministeriais $c$ as atividades administrativas, normativas ou-não, das Agências Reguladoras?

Vejamos, inicialmente, os órgãos envolvidos.

7. As atribuições constitucionais dos Ministérios.

A figura do ministro de Estado remonta o século V da Era Cristã, época em que, no Império Bizantino, já se percebem algumas figuras administrativas de destaque em torno do chefe da gestão "pública" Com o florescer do Estado. a partir do Renascimento, tais figuras se solidificam, absorvendo funções de confiança e de auxilio aos monarcas. ${ }^{20} \mathrm{sem}$ as quais. nos dias de hoje, praticamente não se governa.

No Brasil, os ministros já apareciam na Constituição do Império, sob a qual podiam ser nomeados e demitidos ad nutum pelo Imperador. Nas Cartas posteriores sempre foram abordados, conferindo-lhes diferente grau de exposição ao cenário político e. por vezes, até se lhes impedindo de comparecer ao Congresso, como prescreveu a primeira Constituição Republicana brasileira, de 1891.

$\mathrm{Na}$ Carta Magna, de 1988. diversos dispositivos fizeram referência aus ministros, a saber, os arts. 76, 84, 87 e 88. Além disso, o Decreto-Lei n. 200/67, recepcionado pela Constituição, e a Lei Federal n. 9.649/98 trouxeram diversas provisões específicas sobre as funções e a estrutura ministerial brasileira.

No quadro atual, o Poder Executivo é exercido pelo presidente da República, auxiliado pelos ministros de Estado. os quais são nomeados, entre brasileiros natos ou naturalizados e maiores de 21 anos, e exonerados livremente. Para que isso ocorra. neccssário se faz que, previamente, crie-se o Ministério que irá cheliar. por lei. Quanto às atribuições a ele referentes, a Emenda Constitucional n. 32/01 afastou-as da lei criadora, possibilitando sua disciplina por decreto presidencial. $^{21}$

20. PINTC FERREIRA. Curso de direito constitucional. São Paulo: Saraiva, 1998, p. 390-393.

21. A redação original do artigo 88 prescrevia que "a lei disporả sobre a criação, estruturação e atribuições dos Ministérios". A partir da Emenda Constitucional n. 32, de 2001. a redação foi alterada para os seguintes termos: "a lei disporá sobre a criação e extinção de Ministérios e órgãos da administração pública". Assim, adıquou-se a disposiçào do artigo à nova redação conferida, pela mesma Emenda, ao art. 84. inciso VI. que permite ao presidente da República dispor sobru a organização e funcionamento da administração pública léderal mediante decreto. 
A par disso, relevante é que os ministros de Estado são os auxiliares do presidente da República na tarefa de direção superior da administração federal. Por essa via, os ministros acabam por ligar o Poder Político e a Administração Pública federal. $^{22}$ Isso se evidencia pelas atribuições constitucionais e legais reservadas aos ministros de Estado. especialmente no que toca à chamada "coordenação e supervisão ministerial"

Consoante a atual Carta Constitucional pátria, cabe aos ministros e seus Ministérios: 1) orientar, coordenar e supervisionar os órgãos e entidades da Administração federal que estiverem em sua área de competência; 2) referendar os atos e decretos assinados pelo presidente da República; 3 ) expedir instruções para a execução das leis, decretos e regulamentos; 4) apresentar relatório anual de suas atividades ao presidente da República; 5) e praticar os atos pertinentes às atribuições que lhes forem outorgadas ou delegadas pelo presidente da República.

Além disso, nos termos do Decreto-Lei n. 200/67, os Ministérios ainda têm a função de harmonizar as políticas e programas governamentais com as operações dos órgãos administrativos; coordenar as políticas interministeriais; buscar maior eficiência e menos desperdício de recursos públicos na realização de tarefas; e, inclusive, proteger a administração dos órgãos supervisionados contra interferências e pressões ilegítimas.

A interpretação literal do texto constitucional não evita que, ao orientar, coordenar e supervisionar os órgãos e, outrossim, as entidades da Administração federal sob sua área de competência, a competência ministerial se estenda para além da Administração Direta, sobrepondo-a a entidades da Administração Federal Indireta, incluindo as autarquias vinculadas ao Ministério.

Esta interpretação também se sustenta diretamente nas prescrições do Decreto-lei n. 200/67. mais especificamente ao art. $4^{\circ}$, parágrafo único, segundo o qual "as entidades compreendidas na Administração indireta vinculam-se ao Ministério em cuja área de competência estiver enquadrada sua principal atividade"

Não bastasse isso, ao expedir instruções para a execução de leis, decretos e regulamentos, nada tampouco obsta que os Ministérios extravasem

22. Art. 84, II, da Constituição de 1988. V. especialmente os artigos 10, 15, 25 e 26 do Decreto-Lei n. 200/67. Tambim Silva, José A fonso da. Direito constitucional. São Paulo: Malheiros, 1998, p. 636639. Di Pietro. Parcerias na Administração pública, p. 155. 
novamente sua zona de influência inicial, atingindo a função administrativa dos entes descentralizados. ${ }^{23}$

O fato é que, por vezes, tenta-se imputar uma função mormente política aos Ministérios com o objetivo de afastar sua função de direção e supervisão superior da Administração como um todo. ${ }^{24}$

$\mathrm{Na}$ verdade, a atuação ministerial se assenta em zona cinzenta, na qual o grau das decisões administrativas é tão amplo que se afigura meramente político. Isso, porím, não apaga sua função necessariamente administrativa, que, como se vê pelo teor da Constituição brasileira, conforma tanto a Administração Direta. quanto a Indireta.

Mais, se o exercicio da competência ministerial está ou-não plasmado por mais ou menos política não se trata de um problema exatamente juridico. Se bem observado, em todos os momentos, a Administração está subordinada não apenas pela legalidade estrita, mas também pelas instâncias politicas superiores em virtude de ser o Governo, geralmente, o chefe da Administração, como ocorre no Brasil. Por isso, é até dificil distinguir o que é politico e o que é administrativo - o ato político tem algo de administrativo, e o administrativo, algo de político. ${ }^{25}$ Foi daí que Heras concluiu que a distinção entre essas duas funções é em grande parte uma ficção (ibidem).

De qualquer modo, não se deve olvidar que as atribuições ministeriais são, pelo menos no Brasil, manifestações de uma função administrativa, nos termos caracterizados por Miranda. Contudo, pelo grau de generalidade dessas decisões e pela proximidade e estrutura do órgão administrativo que as toma, naturalmente a função ministerial acaba (por que não?) tornando-se política, no sentido mais partidário da palavra. Lembre-se, ainda, que essa feição mais híbrida da atuação

23. Devemos esclarecer que esta nossa opinião i distinta da sustentada por DI PIETRO. para quem "essas instruções são atos normativos de efeitos apenas internos. dirigidos aos próprios órgãos que compõem o Ministério" Diz assim a autora, porque. no Brasil. praticamente só existem regulamentos de execução, com ressalva feita ao art. 84, VI, da ('R após a Emenda n. 32/01. V. Parcerias na Administração Pública, p. 152 e 153.

24. Lembre-se, ainda, que o art. 19 do Decreto-Lei n. 200/67 dispõe, de modo similar ao art 40. quu: "todo e qualquer órgão da Administração Federal, direita ou indireta, está sujeito à supervisão do Ministro de Éstado competente" com a exceção dos órgãos diretamente ligados ao presidente da República.

25. Por estes mesmos motivos, torna-se muito dificil construir um conceitu juridico de politicas públicas, o qual poderia servir para a distinção exata das competências dos Ministérios e de outros órgãos operacionais setoriais, como as agências reguladoras. 
ministerial continua condizente com a parcialidade e a iniciativa características da função administrativa.

Isso posto, veja-se, então, algo sobre as agências reguladoras para. depois, tentar vislumbrar um relação entrc as funções c os poderes normativos desses dois entes públicos.

8. As atribuições legais das agências reguladoras.

As agências reguladoras, como já se ouviu infinitas vezes, são autarquias especiais marcadas por grande imunidade em relação aos poderes da Administração Direta. Scus dirigentes são estáveis (o que se consagrou com a Lei n. 9.986/01), seu poder normativo é razoavelmente amplo, suas competências de autoorganização administrativa e financeira são razoáveis. Certas vezus, ainda exercem funções quase-jurisdicionais, afora suas competências administrativas de fiscalização. fomento, plancjamento e controle, guardadas as medidas das leis especificas. ${ }^{26}$

Concentrou-se nas agências, em adição, uma função estritamente técnica e setorial, ou seja, voltada a análises da realidade que, por vezes, não apenas supera o Direito e a Política, mas os ignora totalmente, recaindo sobre conhecimentos científicos específicos. Não se quer dizer com isso que a função técnica seja estéril, pelo contrário. Tão importantes são essas atividades que Caetano chegou mesmo a traçar o perfil de uma função estatal técnica, a par das funçõcs clássicas citadas.

Explicou com sua clareza típica o administrativista português que "é, pois, função técnica toda a atividade cujo objeto direto e imediato consiste na produção de bens ou na prestação de serviços destinados à satisfação de necessidade coletivas de caráter material ou cultural, de harmonia com preceitos práticos tendentes a obter a máxima cficiência dos mcios empregados" 27 "Nas agências, da mesma mancira, a função técnica é relevante ao bom e eficiente exercício das outras

26. Nas palavras de ARAGÃO: "“... o traço fundamental das agências administrativas independentes $\dot{e}$ o fato de possuir'm una combinação das funções de legislador, promotor e juiz. Iniciam processos, de oficio ou quando provocadas, julgando-os segundo as normas por elas próprias estabelecidas" (p. 280). In O poder normativo das agências reguladoras independentes e o Estado de direito. Revista de Informação Legislativa. n. 148. outubro-dezembro, 2000, p. 275-299. V. também, do mesmo autor, Agências reguladoras e agências executivas. RDA $228 / 105$ e de BARROSO, Agências reguladoras. Constituição. Transformações do Fstado e legitimidade democrática. RDA 229/285, p. 295 el seq.

27. Op. cit., p. 09. 
funções que the cabem. notadamente a função de administração e composição de interesses públicos e privados dos agentes produtores e consumidores que estão sob sua área de influência.

A par dessa função, digno de nota é que tamanha "liberdade" se conferiu por lei a esses entes controversos, que se convencionou, na doutrina, atribuirIhes o qualificativo de "independentes" $\mathrm{Na}$ verdade. porém. como já reconheceu Sundfeld, "independência é uma expressão certamente exagerada. No mundo juridico, preferimos falar em autonomia. Mas garantir a independência é fazer uma afirmação retórica com o objetivo de acentuar o desejo de que a agência seja ente autônomo em relação ao Poder Executivo (...)" ${ }^{28}$ No mesmo sentido, ARAGÃo afirmou que "muitas vezes supostas inovações não passam, substancialmente, de medidas retóricas, de manifestações de vontade politica" ${ }^{4}$

Modesto, por sua vez, esclarece a tão pregada independência, explicando que "emhora a voz agência seja um modismo, algo desnecessário, não há obstáculo no seu uso pelo legislador. No caso das agências reguladoras, é visivel na nomenclatura a tentativa de uma assimilação do modelo norte-americano das agências independentes: mas a assimilação não foi perfeita. Fala-se abusivament: $\mathrm{em}$ 'capacidade normativa independente' onde o que existe é apenas um grau de autonomia reforçada, maiores garantias funcionais para os dirigentes e uma ampliação na função de intervenção do Estado em setores econômicos e serviços puiblicos delegados" 30

Fin suma, com as devidas cautclas, independência e técnica são as palavras-chaves que sustentam os institutos das agências reguladoras. Trata-se, portanto, de mais um exemplo da consagração da transformação da Administração condicionada, dependente exclusivamente do Poder Legislativo, por uma

28. SUNDFELD, Carlos Ari. Introdução às agências reguladoras. In Direito administrativo econōmico, São Paulo: Malheiros. 2002, p. 23-24.

29. O poder normativo.... p. 279.

30. MODESTO. Paulo. Agências executivas: a orgunização administrativa entre o casuismo e a padronização. RDA $228 / 75$, p. 83 . BARRoso também frisa o vocábulo "autonomia" em vez de "independência". V. Agências reguladoras. Constituição. Transformaçõ̀'s do Estado e legitimidade democrática. RDA 229/285, p. 296. 
Administração condicionante, responsável pela produção de normas de organização interna, quanto de normas que regulam o exercício de direitos individuais. ${ }^{31}$

No tocante especificamente ao poder normativo que lhes cabe, as agências, como fenômeno da administração condicionante, são também responsáveis. junto com outros entes, pela alteração na concepção de lei, da qual se retira o caráter de categoria normativa primária, restrita ao Poder Legislativo. Ai se confirma a idéia de que a lei não é neccssariamente normativa, pois pode ser apenas formal e de efeitos concretos; e, por conseguinte, concluiu-se que o poder normativo se expressa por diversos tipos de diplomas, no exercício até de funções administrativas a jurisdicionais. O poder administrativo, então, também é normativo, tal como o concebe Miranda.

9. Orientações ministeriais e poder normativo das agências reguladoras.

Chega-se então ao fulcro da discussão: se as agências reguladoras detêm poder normativo, qual o bloco de legalidade que se deve sobrepor ao exercício desse poder de modo a guiá-lo? O poder normativo ministerial, que se estende sobre a administração indireta por interpretação das normas constitucionais, permeia o exercício de poder normativo das agências?

Para se delimitar o bloco de legalidade que incide sobre as atividades e o exercicio de poderes das agências é necessário reconhecer, antes de tudo, o tipo de função estatal que exercem. Entendendo-se tratar de funções administrativas e funções técnicas, ficam definidos, portanto, o grau de liberdade e o padrão de legalidade a que esses entes se sujeitam. Resta, apenas, que se busquem as séries normativas relacionadas às suas atividades pela matéria ou área de atuação - daí, por exemplo, a Aneel será primariamente disciplinada pela Lei n. 9.427/96, a Anatel, pela Lei n. 9.472/97; a ANP, pela Lei n. 9.478/97: a Anvisa, pela Lei n. 9.782/99; a ANS. pela Lei n. $9.961 / 00$ e por aí adiante.

31. Sobre a evolução da administração pública, v. CAETANO. ibidem. p. 27 et seq. "Com o andar dus tempos certos órgãos administrativos que simultaneamente são órgãos da soberania (é o caso do governo) foram conquistando o poder de fazer leis. Através dessa faculdade legislativa do seu órgão supremo a Administração conseguiu assim, em larga medida, influir na elaboração das normas que disciplinam a sua competência e a sua acção. E sobretudo nos paises em que os ministros deixaram de considerar-se politicos para se transformarem em chefes adminıstrativos, a faculdade de legislar por decretos-leis representa o dominio da Administração sobre a legislação" p. 29. 
No entanto, não se fecha ai a série normativa. As funções administrativas, ainda quando restritas à execução da lei, são necessariamente parciais e dependentes de iniciativa, ao contrário da execução da lei pelo Judiciário, que é imparcial e dependente de ativação. Desse modo, é preciso buscar novas fontes lagais de atuação.

Entra em cena, então, o poder normativo ministerial.

A relação de legalidade das agências reguladoras, por isso, não se faz apenas em escalonamento linear, partindo-se da Constituição, passando-se pela Lei de criação e chegando ao poder normativo da agência.

Decorrem da Constituição brasileira, de fato, duas linhas mestras superiores ao exercício das agências, um que se condensa na lei de instituição desses entes, e outra, nas normas ministeriais.

Isso não significa que a matéria global e exaustivamente prevista na lei regente das atividades da agência esteja sujeita à ingerência ministerial. No entanto, naquilo em que a Lei aceita uma análise política e, porventura, envolva uma fixação de rumos maiores, governamentais, a influência dos Ministérios por meio de instruções e outras diretrizes parece irretorquível.

Os poderes das agências reguladoras não estão de per se vinculados ao poder normativo ministerial. De fato, a tarefa que revele caráter primordialmente técnico não se poderia sujeitar, de modo algum, a qualquer influência ministerial, restando aí plena "independência" das agências reguladoras ou, melhor dizendo, plena independência dos agentes técnicos, pois nem mesmo a própria agência ou terceiros poderiam direcioná-los ou influenciá-los, sob pena de se infringir os principios da moralidade e da impessoalidade na Administração Pública.

Igualmente, todas as atividades não-normativas, sejam de caráter técnico, administrativo concreto, quase-jurisdicional, hermenêutico, estatístico, científico ou operacional. não estão, ao nosso ver, sujeitas a quaisquer interferências ministeriais. $^{32}$

32. Frise-se bem: não estão sujeitas a ingerências ministeriais, mas "na medida em que $\dot{c}$ perfeitamente possivel o abuso de poder, o arbitrio. o erro, o dolo. a culpa, no estabelecimento de critérios técnicos, também não se pode deixar de reconhecer que a chamada discricionariedadé técnica pode causar lesão ou umeaça de lesão e, portanto, ensejar correção judicial". com base última no principio da unidade de jurisdição. V. DI PIETRO. parcerias.... p. 156. 
Fntretanto, não poderá a agência ignorar as diretrizes ministeriais em decisões que envolvam a tal parcialidade e iniciativa que impregna a função administrativa. notadamente quando a referida função se exerça por atos normativos ou, ainda que não-normativa, haja espaço, vagueza e imprecisão substancial no preceito legal que norteia as atividades.

Havendo função administrativa, há que se levar em conta instruções e diretrizes da Administração superior, harmonizando-as com outros preceitos legais, em hipótese alguma podendo ignorá-las o agente público por força de qualquer dispositivo de lei - ou melhor, a pretexto de qualquer dispositivo.

Nessa linha de raciocínio, as leis instituidoras que tentem afastar as influências dos entes administrativos superiores para permitir que as agências ajam livremente na escolha de seus rumos de atuação estarão indubitavelmente inquinadas de ilegalidade. Em última instância, não poderia a lei ordinária apartar a competência constitucional dos Ministérios, nem excluir suas normas do bloco legal que paira sobre os setores materiais (de mercado, sociais ou técnicos) que regulam esses entes.

Nem mesmo o fenômeno da deslegalização ${ }^{33}$ seria capaz de excluir as normas produzidas em sede ministerial do bloco de legalidade a que se submete uma agência. A deslegalização, trazida por diploma legal, obviamente não seria capaz de esterilizar a função ministerial estabelecida na Constituição, sobrepondo regulamentos às diretrizes ministeriais. Aliás, nem mesmo se a lei de instituição da agência viesse a prever todas as hipóteses de atuação estaria afastada a influência ministerial. ${ }^{34}$

A par dos referidos questionamentos, vejamos um pouco do que fizeram as leis de criação de algumas agências, especificamente no tocante à Administração Superior, ou melhor, à imposição do planejamento, supervisão e coordenação pelos Ministérios.

33. V. MEDAUAR, Regulação e auto-regulação. RDA 228/I28. Cf. também ARAGĩo, Opoder normativo..., para o qual "as leis criadoras das agências reguladoras implicam, pelo menos em matéria técnica, deslegalização em seu favor, salvo, logicamente, se delas se inferir o contrário" p. 291.

34. Nesse caso. acreditamos que as influências ministeriais restariam definitivamente afastadas. Se a lei de instituiçào da agência é de competência do Presidente da República, nos termos do artigo 84 da Constituição, supõe-se que. ao propô-la, de modo detalhado e exaustivo, estaria excluindo a atividade de direção dos Ministros, pois as diretrizes já estariam contidas na própria lei. Não se verifica, porém. hipótese pratica, no Brasil, que siga esse caminho. Se a lei previsse todas as hipóteses de atuação, acaharia não apenas com a influência ministerial, mas com a deslegalização característica do mudelo. 
O art. $1^{\circ}$ da Lei n. 9.472/97, que instituiu a Anatel. dispôs que compete a União organizar os serviços de telecomunicações nos termos das políticas estabelecidas pelos Poderes Executivo e Legislativo (vide ainda as competências do art. 18$)^{35}$ Já os arts. $1^{\circ}$ e $2^{\circ}$ da Lei n. 9.478/97, que cria a ANP, determinaram algumas diretrizes legais da política nacional, deixando ao Conselho Nacional de Política Energética a atribuição de propor novas políticas. Vale dizer que o Conselho é vinculado à Presidência da República e presidido pelo ministro de Minas e Energia.

A Lei n. 9.782, que instituiu a Anvisa, foi mais respeitosa, deixando expressamente à União a tarefa de definir a política nacional de vigilância sanitária e exercer o poder normativo, nos termos do art. $2^{\circ}$, I. O parágrafo $1^{\circ}$ do mesmo dispositivo ${ }^{36}$ desejou separar a atuação dos Ministérios e das Agências, como se cada um dos entes tivesse competências privativas, em detrimento das disposições constitucionais (art. 87) e da séria normativa que é comum.

De outra parte, a Lei n. 9.961/00 criou uma estrutura intersssante. A ANS proporá as políticas e diretrizes gerais ao Conselho Nacional de Saúde Suplementar que, se aceitas, serão implementadas pela agência. Assim, a ANS obrigatoriamente se comunica com a administração superior, dentro de uma mesma linha de normas, respeitando a competência ministerial, diferentemente do que parece ocorrer na estrutura da Anvisa. Além do mais, o descumprimento injustificado do contrato de gestão firmado entre a ANS c o Ministério da Saúde implicará a dispensa do Diretor-Presidente da agência mediante solicitação do ministro.

Por fim, a Lei n. 9.984/00, que institui a ANA, atribuiu ao Conselho Nacional de Recursos Hídricos o planejamento do setor, colocando a agência como executora das politicas escolhidas, em harmonia com as atribuições administrativas superiores.

Em suma, como bem ressaltou Sundfeld, "os Ministros têm de realizar a supervisão dos diferentes órgãos e dos entes da Administração indireta, os quais,

35. Por mais que se tenha tentado forjar grande autonomia para Anatel. note-se que o seu artigo 19. inciso I, resgata a vinculação às dirctrizcs superiores ao estatuir que cabe a agência implementar a politica nacional de telecomunicações. Naturalmente, tal politica não se esgota nos mandamentos do artigo 18, abrindo espaço a cumplementaçōes governamentais.

36. A saber: Lei n. $9.782 / 99$, art. $2^{\circ}, \S 1^{\circ}$ - A competência da União serả exercida: I - pelo Ministério da Saúde. no que se refere à formulação, ao acompanhamento e à avaliaçào da politica nacional (...); II - pela Anvisa, em conformidade com as atribuições que lhe são confuridas por esta Lei (...). 
portanto, não podem funcionar como se fossem 'Estados independentes isto é, verdadeiros Estados ao lado do Estado" 37

A independência das agências, propalada por todos os cantos, não pode ser compreendida sem a consciência das forças retóricas que a justificam. Não se pode, em detrimento do sistema de competências constitucionais e das relações imperativas de juridicidade, mascarar o bloco de legalidade que conforma essas novas autarquias especiais, sob objetivos outros, muitas vezes falaciosos e frágeis. Longe, porém, de se pregar a extinção do modelo regulador que se construiu no Brasil. ${ }^{38}$

Ademais, não se entenda pela inserção da influência ministerial no modelo regulatório qualquer tentativa de colocar as normas setoriais hierarquicamente abaixo das diretrizes gerais. Na verdade, o termo administração federal superior não guarda em si uma superioridade normativa, mesmo porque, vale dizer que uma relação hierárquica é uma relação de superioridade e inferioridade, que a lógica nãoexplica: as inferîncias lógicas se dão entre antecedentes e conseqüentes, mas antecedência não-significa superioridade, nem conseqüência, inferioridade. ${ }^{39}$

10. Conclusão: um retorno à legalidade como compatibilidade.

Caetano faz bem claro que "o desenvolvimento da atividade administrativa segundo normas juridicas gerais corresponde, pois, a uma dupla necessidade: de justiça para os cidadãos e de eficiência para a própria

37. O comentário do nobre administrativista, no contexto, não denota qualquer predileção à aproximação entre entes da administração superior e agências reguladoras. A respeito, ibidem, p. 26-27.

38. O interesse real é apenas de atacar o mito de "independência" dessas autarquias, resgatando o valor dos Ministérios, constitucionalmente consagrado. Aliás, note-se que a independència agora tem começado a ser utilizada como mecanismo político partidário às avessas. A direção da agência é estabelecida de acordo com a ideologia politico-partidária do governante, mas prolonga-se no tempo, penetrando uma nova gestão. Ai. vale-se da tal independência para poder ignorar as diretrizes governamentais ou, o yue é pior, para enfraquecer o governo, contrariando suas diretrizes, tomando medidas impopulares entrc outras coisas. São essas e outras coisas que nos levam a crer que engenharia juridica não substitui ética humana.

39. FERRAZ JÚNIOR, op. cit., p. 186. O autor. porém, afirma que o ordenamento não é um sistema totalmente lógico. Nós, porém. propositalmente o consideramos como tal. 
Administração. E o saber antecipadamente como proceder é, quer para os cidadãos que para os órgãos administrativos, uma garantia essencial de segurança" 40

Ora, a segurança e até a própria eficiência, desta feita, estão vinculadas a um padrão de legalidade administrativa. Assim sendo, mais um motivo para se inserir na mesma cadeia normativa o poder diretivo constitucional dos Ministérios e o poder das agências reguladoras. A eficiência, ainda que em sentido amplo, não é incompativel com a legalidade. Incompatível, sim, é a burocracia sem razão, no sentido negativo da expressão.

A atividade normativa dos Ministérios pode vincular e dirigir a atividade das agências, como se viu acima. Isto não-significa, de modo algum, uma afronta à eficiência ou mesmo a autonomia legal que envolve os últimos entes. Implica apenas que o bloco normativo do agente público que age no âmbito dessas autarquias não pode ignorar normas ministeriais que componham o bloco de legalidade, sob o qual sua atividade se exerce.

Em outras palavras, a formulação da vontade institucional das agências, principalmente quando se manifesta no exercício do poder normativo, não pode prescindir de coerência à Administração Superior, pois aí sim seria ineficiente.

Aliás, talvez valha, por fim, retomar algumas das concepções sobre o princípio da legalidade administrativa para se desvinculá-la definitivamente da idéia de desorganização e ineficiência, compatibilizando-a com certa discricionariedade.

Há décadas atrás, Eisenmann forjou brilhantemente um conceito de legalidade que tanto poderia corresponder a uma conformidade de normas, atos e condutas em relação a normas superiores, ou a uma compatibilidade daquelas às últimas. Naquele primeiro caso, a legalidade implicaria fazer apenas o que se estivesse permitido ou obrigado: e, no último, autorizaria fazer tudo o que não estivesse proibido pelo ordenamento. ${ }^{41}$

Na relação de conformidade, o princípio da legalidade é tomado em acepção máxima e estrita, e pela qual dele decorre a obrigação de a Administração

40. Op. cit., p. 29. A respeito, DI PIETRO explica algumas razões contrárias trazidas pela doutrina contemporânea sobre a tensão existente entre legalidade e eficiência administrativa. V. Discricionariedade administrativa na Constituição de 1988. São Paulo: Atlas, 2001, p. 58-59.

41. EISENMANN, Charles. O direito administrativo e o principio da legalidade. RDA, Rio de Janeiro: Renovar, v. 56, abril-junho, 1959, p. 47 et seq. 
agir em sempre na presença da lei. Por este padrão fucchado, todo ato não-previsto por uma regulamentação superior e abstrata deve ser inquinado de ilegalidade.

De outro lado, na compatibilidade, tem-se um padrão mínimo de legalidade, que consiste na necessidade de não-contrariedade entre atos administrativos e a lei, ou o Direito. Aqui, chega-se à conclusão de que a Administração pode praticar todos os atos que não sejam previstos ou formulados em Lei, ou seja, como se disse, pode fazer tudo o que não Ihe seja proibido.

Não scria prudente. contudo, escolher um padrão de legalidade dentre os dois apresentados. Fm cada série normativa do ordenamento esses padrões podem conviver ou mostrarem-se isolados. Veja-se, por exemplo, que o padrão legalidade que envolve o sistema tributário é muito mais forte que o das atividades estatais de planejamento e fomento da economia (seja na iniciativa de trabalho. consumo ou empresa), disciplinada pelo art. 174 da Constituição da República.

Mesmo em um caso entre dois órgãos administrativos podem existir os dois padrões de legalidade ou apenas um deles. De forma própria, especificamente na relação que se impõe sobre os poderes das Agências Reguladoras e os entes da Administração Pública superior, também existe um padrão de legalidade. Resta saber. porém, qual deles ou se ambos estão presentes.

Cremos que. dentro da engenharia constitucional brasileira, os dois padrões permeiam a relação Ministérios x Agências. De fato, em tudo que não haja remissão direta a regra jurídica ministerial, a relação entre os Ministérios e Agências deve guiar-se por uma legalidade fraca ou por uma relação de compatibilidade ou não-contrariedade. Esta relação de legalidade, naturalmente, dependerá da existência de planos de ação governamental claramente definidos nas respectivas esferas de ação, por exemplo, energia, petróleo, água, saúde etc. ${ }^{42} \mathrm{~A}$ legalidade como

$42 \wedge$ existência de políticas públicas postas é fundamental para que uma relação de legalidade exista entre agências e ministérios. Sem tais políticas públicas setoriais, definidas pelos Ministérios, impossivel seria descabido exigir ações compativeis ou conformes justamente pela ausência de um padrão para julgá-las como tal. Não foi por outro motivo que este assunto especificamente lembrado no relatório interministerial "Análise e avaliação do papel das agências reguladoras no atual arranjo institucional brasileiro", documento aprovado pelas Câmaras de Infra-estnıtura e Politica Econômica da Casa Civil em agosto de 2003. Literalmente, consta do citado relatório que "a inação ou omissâo dos órgãos propositores e formuladores de politicas setoriais tem gerado orientaçós dispersas que dificultam a coordenação da ação governamental". p. 28. 
conformidade seria excepcional, existente apenas quando a Lei de criação apontasse para a norma ministerial, tal como ocorre na área do petróleo e da saúde. ${ }^{43}$

Seja como compatibilidade, seja como conformidade, fato é que nunca poderia a Lei instituidora da Agência ignorar ou tentar imunizar o ente criado do poder normativo ministerial, assegurado constitucionalmente.

Assim, tendo como regra a necessidade de uma legalidade de nãocontrariedade entre esses dois entes, respeitada estariam as determinações constıtucionais e, concomitantemente, a eficiência das agências, sem falar no resguardo imediato dos interesses públicos e privados que a legalidade busca tutelar.

Mais que isso, o reconhecimento da relação de legalidade, por meio de compatibilidade ou conformidade, impediria a fragmentação da vontade institucional do Estado, o que. para os administrados, gera descrença, desconfiança e incertezas, inclusive juridicas e, para a Administração Pública, prejuizos e perda de legitimidade.

São Paulo, dezembro de 2004.

\section{Referîncias bibliográficas.}

ARAGÃO, Alexandre Santos. O poder normativo das agências reguladoras independentes e o Estado democrático de Direito. Revista de Informação Lc'gislativa, Brasilia, n. 148, p. 275-299, out./dez. 2000.

ARAGÃO, Alexandre Santos. Agências reguladoras e agências executivas. Revisıa de Direito Administrativo, Rio de Janeiro, v. 228, p. 105-122, abr./jun. 2002.

BARROSO, Luís Roberto. Agências reguladoras. Constituição. Transformações do Estado e legitimidade democrática. Revista de Direito Administrativo. Rio de Janeiro: Renovar, v. 229, p. 285-311. jul./set.. 2002.

BOBBIO, Norberto. Teoria do ordenamento juridico. Brasília: Fditora Universidade de Brasília. 1999.

CAETANO, Marcello. Manual de direito administrativo. Rio de Janeiro: Forense. 1970.

43. No caso do Petróleo, a relação de conformidade legal se dá com o Conselho Nacional de Política Energética - CNPR e é determinada pelo art. 20 da Lei n. 9.478/97. No caso da saúde, a relação de conformidade da ANS se dá com o Conselho Nacional de Saúde Suplementar. Consu, por força do art. 40 da Lei n. 9.961/2000. 
CANOTILHO, Joaquim José Gomes. Direito constitucional e teoriu da constituição. 5. ed. Coimbra: Almedina, 2002.

DI PIETRO, Maria Sylvia Zanella. Discricionariedade administrativa na Constituição de 1988. São Paulo: Atlas, 2001.

DI PIETRO, Maria Sylvia Zanella. Parcerias na Administração Pública. São Paulo: Atlas, 2002.

EISENMANN, Charles. O direito administrativo e o princípio da legalidade. Revista de Direito Administrativo, Rio de Janeiro: Renovar, v. 56, p. 47-70, abr./jun. 1959.

FERRAZ JUNIOR, Tércio Sampaio. Introdução ao estudo do direito: técnica, decisão, dominação. São Paulo: Atlas, 1994.

FRANCO SOBRINHO, Manoel de Oliveira. Obrigações administrativas. Rio de Janeiro: Forense, 1983.

GRAU, Eros Roberto. O direito posto e o direito pressuposto. São Paulo: Malheiros, 2000.

HERAS, Jorge Xifras. El gobierno y la funcion política. In Gobierno y administracion em la constittucion. Espanha: Instituto de Estúdios Fiscales, 1988, p. 1843-1851.

JUSTEN FILHO, Marçal. O direito das agências reguladoras independentes. São Paulo: Dialética, 2002.

KELSEN, Hans. Teoria pura do direito. São Paulo: Martins Fontes, 1998.

LARENZ, Karl. Derecho Justo. Madrid: Civitas, 1985.

LAUBADĖRE, André de. Direito público econômico. Coimbra: Almedina, 1985.

MEDAUAR, Odete. Regulação e auto-regulação. Revista de Direito Administrativo, Rio de Janeiro, v. 288, abr./jun. 2001.

MIRANDA, Jorge. Teoria do estado e da constituição. Rio de Janeiro: Forense. 2002.

MODESTO, Paulo. Agências executivas: a organização administrativa entre o casuísmo e a padronização. Revista de Direito Administrativo, Rio de Janeiro: Renovar, v. 228, p. 75-84, abr./jun. 2002.

PINTO FERREIRA. Curso de direito constitucional. São Paulo: Saraiva, 1998.

SILVA, José A fonso da. Direito constitucional. São Paulo: Malheiros, 1998.

SUNDFELD, Carlos Ari. Introdução às agências ruguladoras. In Direito administrativo econômicu. São Paulo: Malheiros, 2002. p. 17-38.

ZANOBINI, Guido. L'attlività amministrativa e la legge. Milão: Giuffrè, 1955. 